\title{
TOP1 wt Allele
}

National Cancer Institute

\section{Source}

National Cancer Institute. TOP1 wt Allele. NCI Thesaurus. Code C50382.

Human TOP1 wild-type allele is located within 20q12-q13.1 and is approximately $96 \mathrm{~kb}$ in length. This allele, which encodes DNA topoisomerase 1 protein, plays a role in transcriptional enhancement and alteration of single-stranded DNA structure. 